\title{
Assessment of Urban Domestic Water Demand and Supply in Edo North, Nigeria
}

\author{
Bada O.A., Alhassan A.I., Momoh E.O, Olotu Y., Osagioduwa M., Dirisu H.I.,Ayilaran C.I.
}

\begin{abstract}
An exponential increase in the global population has seriously put pressure on land and water resources. It is projected that $33 \%$ of the worldwide people will be highly water-stressed by the 2050s if effective strategies are not developed. The study assessed urban domestic water demand and supply in Edo North senatorial district in Edo State, Nigeria. This is with the view of exploring some critical water resource variables to determine water security, distribution, and accessibility of safe drinking water in Edo North in Edo State in Nigeria. Integrated Water Resource Management Tools (IWRT) such as Water Poverty Index (WPI) and Water Accessibility Indicator (WAI) was applied. The results show that Auchi is highly water-stressed at the Estako-west area with MPI and WAI values of 0.24 and 0.33 . Conversely, Okpella and Agenebode in Eskako central have MPI and WAI values 0.34 and 0.31 , and 0.31 and 0.32. Sabo Gida Ora and Isobe in Owan East and West have better safe drinking water coverage and accessibility with the indicator values of $0.54,0.53$ [WPI], and 0.61 and 0.59 [WAI]. It is generally observed that the supply of potable water in the Edo North is highly unsecured and unsustainable to meet the current and future demand. Valuable and economic time is wasted to gather water from an average closest distance of $1.3 \mathrm{~km}$ from home to some designated water taps. In conclusion, it is imperative to design a robust integrated water policy that should include Private-Public-Partnership (PPP) to invest in the provision of safe drinking water.
\end{abstract}

Keywords: Water Poverty Index, Water stress, Safe drinking water, Edo North, Private-Public-Partnership.

\section{INTRODUCTION}

$\mathrm{W}$ man. It's importance to the existence of man and life in its entirety cannot be overemphasized. Aside from food, shelter and clothing, availability of water is at the heart of man's sustenance

Manuscript received on April 03, 2021.

Revised Manuscript received on April 20, 2021.

Manuscript published on June 10, 2021.

* Correspondence Author

Bada, O.A.*, Department of Urban \& Regional Planning, Auchi Polytechnic, Auchi, Edo State, Nigeria. Email: afolabibada@yahoo.com

Alhassan A.I, Department of Civil Engineering, Auchi Polytechnic, Auchi, Edo State, Nigeria: Email:ahmedalhassan001@gmail.com

Momoh E.O.: Department of Urban \& Regional Planning. Eng., Auci Polytechnic, Auchi, Edo State, Nigeria Email:emmanuelonuchemomoh@gmail.com

Olotu Y., Department of Agricultural \& Bio-Envi. Eng., Auci Polytechnic, Auchi, Edo State, Nigeria. Email:realyahaya@yahoo.com Osagioduwa, M. Department of Urban \& Regional Planning, Auchi Polytechnic, Auchi, Edo State, Nigeria. Email: wilosag@yahoo.com

Dirisu H.I, Department of Civil Engineering, Auchi Polytechnic, Auchi, Edo State, Nigeria: Email:henry.dirisu@gmail.com

Ayilaran C.I., Department of Agricultural Technology, Auchi Polytechnic, Auchi, Nigeria.

(c) The Authors. Published by Lattice Science Publication (LSP). This is an open access article under the CC BY-NC-ND license (http://creativecommons.org/licenses/by-nc-nd/4.0/)
[1]. Water is acknowledged all around the earth as a vital natural resource that is key to the existence of man and that it is a chief factor that drives the progress of civilization [2]. In fact, sustaining life and biodiversity on earth is largely dependent on water, thus, effective and efficient management of this socially sensitive resource is crucial to its sustainability [3].

Accessibility, distribution, and affordability of safe drinking water are very important to socio-economic and human development index of any nation. According to Adedayo and Ifabiyi [4], the case of accessibility to potable water supply is that of fundamental human right. The quantity of this water resource that is needed for various levels of domestic use is regarded as "domestic water demand." The amount of domestic water consumption varies depending on the standard of living the consumers in rural and urban areas. Water consumption for domestic purposes are often in the form of drinking; preparation of food as well as cooking; dish washing, household laundry; cleaning the house and polishing vegetable gardening; rearing of domestic livestock among other uses. Consequently, the amount of water consumed by a household (domestic water demand) is greatly determined by the size of the family or the household size, the nature of water consuming appliances that are being utilized within the household and the amount of income earned by the household [5].

There is enormous quantity of water on the earth. In fact, research has shown that about $71 \%$ of the earth's lithosphere is covered by approximately 360, 000,000 cubic kilometers of ocean water [5]. Apart from this, water exists in the atmosphere as moisture, in streams, rivers, lakes and even beneath the earth as underground water. Conversely, of this water mass available, only $3.1 \%$ is freshwaters [5]. More worrisome is the fact that the continuous rise in human population which results to more human activities and the quick depletion of natural resources amplifies the demand for potable water in the quest for survival. According to Al-Amin and Mahmud[2] there has been a hike in the extensive use of water on a global scale, however, the efficiency of the supply of water is questionable when matched with this increased demand resulting from the drastic hike in global population; advancement in technology and global economic growth. This is more so as the accelerated activity of the human population progressively pollutes the limited freshwater supplies, making the already critical state of water supply even more acute [6]. There is lack of uniformity as regards the demand of water and its supply in most countries around the world. This is because of its dependence on a host of human and environmental factors such as climate change, location, characteristics of the household and a lot of other socio-economic factors [4] 
Water quantity and availability is a major challenge in developing nations; the issue of climate change further complicated the already complex situation. It has also been shown that the already gross imbalance between the availability of freshwater and its use could even become more intense by the activities of climate change [7]. In the last four decades, the world's population has increased quadruple, and this development has also increased the demand for potable water globally. However, the investment on water supply does not commensurate with the reality on ground. This is because the hike in urban population is not accompanied with the upgrading of water supply services $[4,8]$. The investment in water supply does not commensurate with the growth in population [4]. This is accompanied with dramatic variations in infrastructure expenditure between cities in high and low income countries [8].

The challenge of accessing safe drinking water has been a huge issue in the region before the advent of population explosion. According to WHO/UNICEF[9] 1.1 billion people lack access to improved water supply. In the same vein, the data released by the Nigeria Bureau of Statistics in 2006 confirmed that only $51.4 \%$ of Nigerian have access to safe water with only $43.4 \%$ having access to all year round supply. This situation is often more intense in the urban areas. One of the most important problems of urbanization across the world is that of water supply, because of its role in natural health and economic development. According to Ifabiyi and Ahmed [10], it was confirmed that in 1990, 71.1 million Nigerians lived in urban areas, in 1995 it increased to 96.1 million, by 2003 this percentage had gone to 136 million people, indicating a serious stress in water supply in Nigerian cities.

Findings from several studies has indicated that the poor and marginalised groups are faced with higher risk of not only inadequacies in water supply but also consuming contaminated water from such sources as surface water and unprotected wells. Also, the Central Bank of Nigeria CBN (2004) reported that $51 \%$ and $41 \%$ of Nigerians are women and children respectively. This suggests that a greater percentage of the population of Nigeria remain vulnerable to water related health issues. This is also supported by the report of Annad[11] which opined that despite the fact that water crisis is seen to be a general problem embattling developing nations, the greatest burden is born by women who by the reason of their social gendered roles which includes collecting water needed for the sustenance of the household. This often involves trekking long distances to collect water for domestic uses. According to the standards of the WHO[12], areas whose source of water supply is farther than $1000 \mathrm{~m}$ or more than $30 \mathrm{~min}$ uses of the total collection time pose a great threat to human health. They are also compelled to purchase informally-vented water at higher prices and rely on time-demanding approaches for collecting water, such as hand pumps or stand posts $[5,7,8]$.

Understanding the quantity of household water demand is an important aspect of urban water supply [3]. However, this is a complex phenomenon as water demand varies widely on the basis of socio-economic factors [10] The study of water supply and demand in Nigeria becomes imperative in various respects. Having noticed that accessibility and affordability of safe drinking water is moving out of reach in Edo North, Nigeria, this study investigates the coverage of the safe drinking water in response to the growing population using integrated water resource indicators such as WAI and WPI.
The outputs of the study are expected to be used in formulating integrated water resource framework useful to address water insecurity in Edo North, Nigeria.

\section{MATERIALS AND METHODS}

\section{A. Study Area}

Edo North is one of the three senatorial districts in Edo State, Nigeria. The district has six (6) local government areas (Etsako west, Estako central, Estako east, Owan south, Owan central and Owan east). The inhabitants of these communities are people who engage in farming and trading as a source of livelihood coupled with civil/public servants. The study area is relatively characterised by low to medium population density communities, however, auchi town which is the local government headquarter of Etsako West local government area has a high population density. This is due to the influx of people as a result of its strong educational and links. This is so as Auchi town is the seat of a renowned federal polytechnic which has encouraged the influx of people to the area for both commercial and educational activities. In addition, Edo North is positioned between latitude $06^{\circ} 07^{\prime} \mathrm{N}$ and $07^{\circ} 06^{\prime} \mathrm{N}$ of the Equator and between longitude $05^{\circ} 07^{\prime} \mathrm{E}$ and $06^{\circ} 08^{\prime} \mathrm{E}$ of the Greenwich meridian as shown in figure 1. Edo North covers a total land mass of about $6169 \mathrm{~km} / \mathrm{sq}$ [17]; home to a total population of 955791 persons. According to the 2006 population census, the female population of Edo North is put at 483000 persons while the male population is put at 472791persons [17]. Edo State in general is bounded by Delta State to the south, Ondo State to the west; Kogi State to the North and Anambra State to the east. See Fig.1 showing Nigeria, Edo State and Edo north which is the study area.

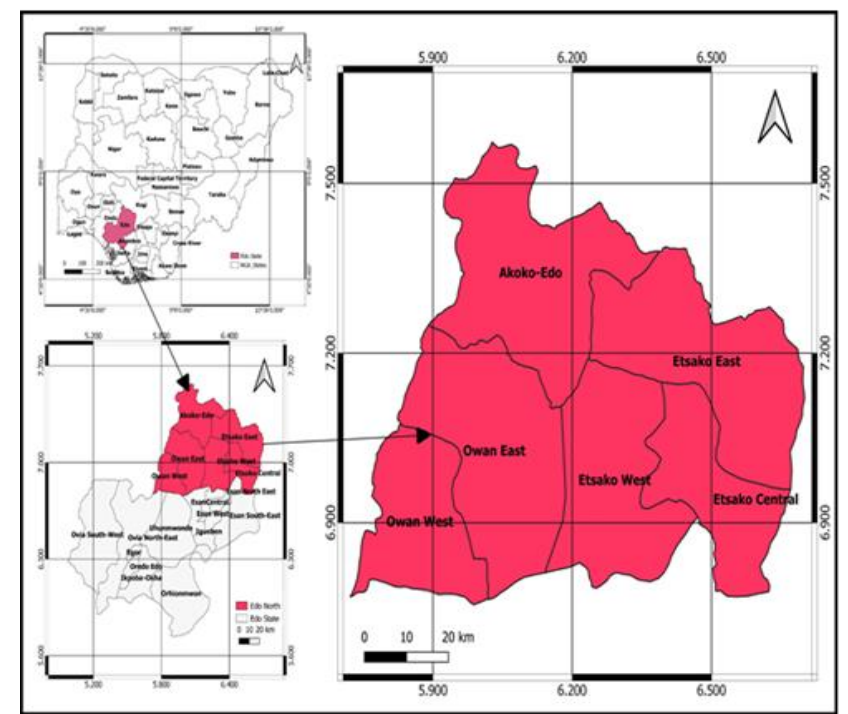

Fig. 1: Nigeria showing Edo state and Edo North (study area)

Source: Author's GIS Lab, 2021. 


\section{B. Water Poverty Index}

WPI is the simplest indicator to measure the accessibility of safe drinking water in a given region or community. The main variables used for inputs are the time $(t)$ spent to gather a given volume (V) of potable water. However, factors such as cost (c) of water, storage facility (SF), and seasonal variation (SV) are also embedded to estimate the water poverty index. Region WPI can be calculated using equation (1)

$$
\begin{aligned}
& \text { WPI }=\frac{\mathrm{T}}{\mathrm{V}} \\
& \mathrm{f}(\mathrm{c}, \mathrm{s}, \mathrm{SV})
\end{aligned}
$$

\section{Water Accessibility Index}

The WAI would be formulated using a set of variables that will portray the core of the data being assessed. This is achievable by utilizing the national scale data (a top to bottom approach). This can also be done at a local level through locally determined variables and factors (a bottom to top approach). Using the composite index approach, the WAI could comprise various elements, such as:

(i) availability of water,

(ii) accessibility of safe water,

(iii) cleanliness and sanitation, and

(iv) time used to get water for domestic purpose [6]. WPI can be estimated using equation (2):

WAI $=\frac{1}{3}\left(\mathrm{~W}_{\mathrm{g}} \mathrm{A}+\mathrm{W}_{\mathrm{g}}+\mathrm{W}_{\mathrm{t}}(100-\mathrm{T})\right.$

Where, $\mathrm{w}_{\mathrm{a}}, \mathrm{w}_{\mathrm{s}}$ and $\mathrm{w}_{\mathrm{t}}$ represents weights attributed to individual component of the WAI (such that $\mathrm{w}_{\mathrm{a}}+\mathrm{w}_{\mathrm{s}}+\mathrm{w}_{\mathrm{t}}=1$ ) $[13,14]$.

\section{RESULT AND DISCUSSION}

\section{A. Water Demand and Supply}

Figure 2 presents the relationship between the volume of household water demand and supply over the study region. The result Figure 2a indicates that Estako west local government area (LGA) has the least values of $\mathrm{R}^{2}=0.276$, this indicates that there is a rather poor relationship between the household water demand and supply in Etsako west LGA of Edo state. Conversely, this is not the case in Akoko Edo LGA of Edo State as the result in figure 2b shows an $\mathrm{R}^{2}$ of 0.488 indicating a fair relationship between the water demand and supply in Akoko Edo region. Most of the people living in these communities are low income earners whose average daily living falls below 2USD. Consequently, all their water sources are not sustainable, they are seasonal and weather driven. To achieve consistency in WPI across countries, international coordination is required [13]. There is need for some global effort towards capacity building, this is needed both to help in extending local capacities as well as training to enable continued surveys without support from external bodies [13].

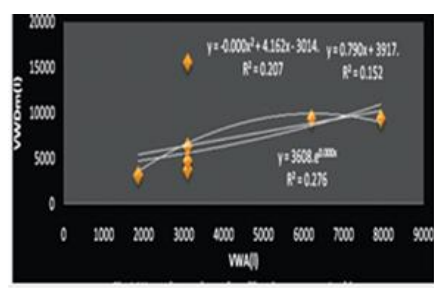

Fig.2a

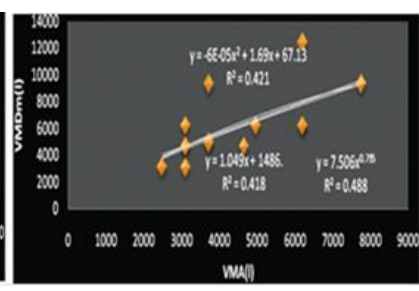

Fig.2b
Fig. 2: Relationship between water demand and supply in Estako-West (a) and Akoko Edo (b)

\section{B. Performance of Integrated Water Resources Management (IWRM) indicators}

Table 1 presents the Water Poverty Index and Water Accessibility Index for all the Local Government Areas that constitute the study. The result presented in Table 1 indicates that that Estako West LGA has the highest WPI and WAI of $0.80 \mathrm{~min} / \mathrm{l}$ and 0.84 using a base rate of 100 litres during the dry season. Whereas Akoko Edo LGA recorded the least WPI and WAI at $0.55 \mathrm{~min} / \mathrm{l}$ and 0.58 respectively. The higher the WPI and WAI values, the lower the access to safe drinking water. The measurement range of each of the IMWT is from 0.00 to 1.00 . The value $0.00-0.30$ indicates very high-water accessibility, $0.31-0.50$ is high, $0.51-0.60$ is fair, $0.61-0.80$ is water stressed, and 0.81-1.00 is highly water stressed. From this categorization, it showed that Estako Central, Estako East, Owan West and Owan East are water stressed, while Estako West is highly water stressed, Akoko Edo has fair water accessibility and coverage [Table 1, Fig. 3]. Conversely, the presence of Ojirami multipurpose dam depressed the water-stress condition of Akoko-Edo. The finding is in agreement with the study of Komives[14] which reported that that the most water-stressed region in Ondo State followed by Ilaje, while water stress was considered minimal at OndoWest and Ose LGA through wet and dry seasons. It is vital to measure water stress using different indicators, compare the observation and determine urban water security level. Johnstone[13] andMerrett[15]reported that some data on availability and use of water can be found in some countries, widespread datasets are quite rare [16].

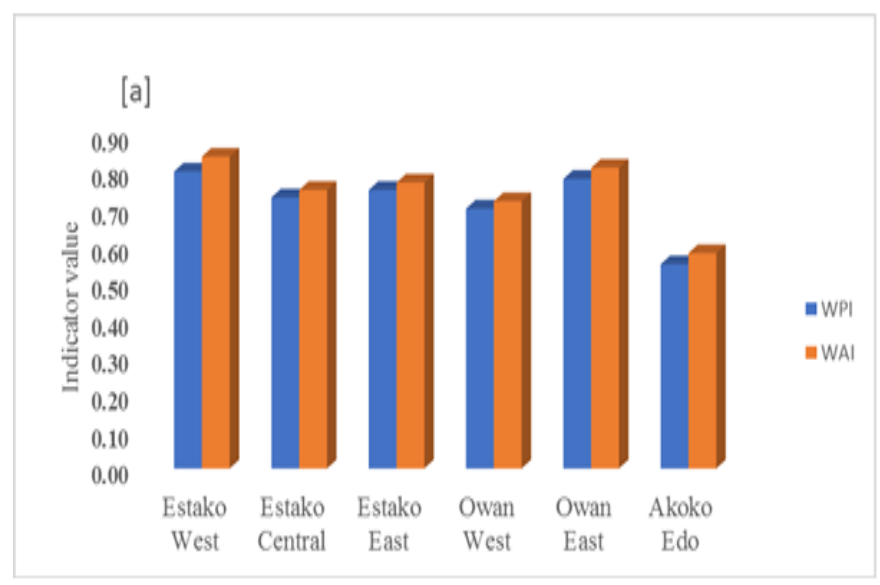

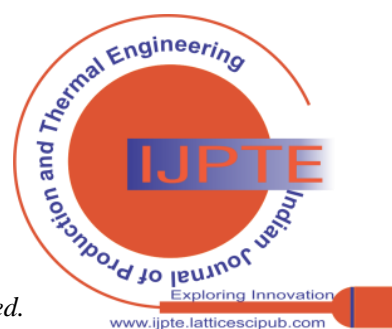


Table 1. WPI and WAI values for all the local government areas in Edo North, Nigeria-

\begin{tabular}{|l|l|l|l|l|l|}
\hline S/N & L.G.A & $\begin{array}{l}\mathbf{T}_{\mathbf{T}} \\
(\mathbf{m i n})\end{array}$ & $\begin{array}{l}\mathbf{T}_{\mathbf{V}} \\
(\text { liters) }\end{array}$ & WPI & WAI \\
\hline 1 & $\begin{array}{l}\text { Estako } \\
\text { West }\end{array}$ & 80 & 100 & 0.8 & 0.84 \\
\hline 2 & $\begin{array}{l}\text { Estako } \\
\text { Central }\end{array}$ & 73 & 100 & 0.73 & 0.75 \\
\hline 3 & $\begin{array}{l}\text { Estako } \\
\text { East }\end{array}$ & 75 & 100 & 0.75 & 0.77 \\
\hline 4 & $\begin{array}{l}\text { Owan } \\
\text { West }\end{array}$ & 70 & 100 & 0.7 & 0.72 \\
\hline 5 & $\begin{array}{l}\text { Owan } \\
\text { East }\end{array}$ & 78 & 100 & 0.78 & 0.81 \\
\hline 6 & $\begin{array}{l}\text { Akoko } \\
\text { Edo }\end{array}$ & 55 & 100 & 0.55 & 0.58 \\
\hline
\end{tabular}

\section{CONCLUSION}

The study applied to Integrated Water Resources Tools such as WPI and WAI to measure water security in Edo North, Edo State. The indicators showed that five out of six local government areas in the Edo North region are highly water-stressed. Estako-West is the most water-stressed region with an index of 0.80 (WPI) and 0.84 (WAI). At the same time, Akoko Edo has fair water coverage with 0.55 and 0.58 index values. It is well-intentioned to understand that for a region to be water secured, the least indicator values fall between 0.00-0.45 under any of the two applied indicators. The current water security of the study area is highly threatened. Conversely, it is crucial to address the situation before it is entirely out of hand. Some of the strategies to adopt in handling the case are for the government at every level to invest in water resources provision and management through the introduction of Public-Private-Partnership (PPP).

\section{ACKNOWLEDGMENT}

The authors wish to thank Engr. Olotu Yahaya for his contributions to this research as a data analyst. Also the efforts of Mr. Ojonimi Alfred in proof-reading and editing the manuscript is greatly appreciated.

\section{REFERENCES}

1. Ajadi, B.S. (1996); Pattern Of Water Supply In Ilorin City, Unpublished B.Sc. Thesis Department Of Geography, Unilorin.

2. Al-Amin, M. And Mahmud, K. (2011) Domestic Water Consumption Patterns In A Village In Bangladesh. Islamic University Of Technology, Gazipur Bangladesh.

3. Nnaji, C. C., Eluwa, C., \& Nwoji, C. (2013). Dynamics of domestic water supply and consumption in a semi-urban Nigerian city. Habitat International, 40, 127-135. doi:10.1016/j.habitatint.2013.03.007

4. Adedayo, A.F. And Ifabiyi I.P (1999) The Distribution of Water and Role of Public Agencies In Kwara State. Journal of Social And Management Studies, 6(1) $97-111$.

5. David L. B, (2007). Developing Countries provision of water to the poor: Tariffs Role and Subsidies, from the Dept. of Eco. and Soc. Affair of the UN Secretariat (UN-DESA). Sust. Dev. Div.

6. Fernando R. and Meike V. G., (2006). Water Supply and Sanitation Evaluation. 23(1): 34-53

7. Hassanali, C. (2005). Public Services Corruption: South Asia's Experience on Water and Sanitation Sector. World Dev. 32 (1): 53 71.

8. Hassanali, C. (2005). Developing Countries; Integrated Water Resc MGT. Evaluation of Water Supply and Sanitation. 23 (1): 60 - 72
9. WHO/UNICEF (2000). Global Water Supply and Sanitation Assessment 2000 Report, WHO Geneva.

10. .Ifabiyi, I.P. And Ahmed, A. (2011) Determinants of Household Water Demand In Traditional City: Example From The Western Axis Of Ilorin,Nigeria. Asia Africa Journal of Economics And Econometric 2 (2): 335 - 408 .

11. .Anad, P.B. (2007) Right to Water And Access to Water: An Assessment Journal. Int. Development (19) 511 - 526.

12. World Health Organization (2003). Guidelines for Drinking Wate Quality, Volume 1. Recommendations 2nd Edition.

13. Johnstone, T. (2000). Rural Water Service Demand; The Instrumental Variables Approach. Southern Eco. Journal 53 (2): 333 - 346.

14. Komives, (1999). Côte d'Ivoire's Water Supply; A Proposal for Social Pricing. Journal of Dev. Eco. 88(2): 258-268.

15. Merrett, C.T. (1997). Appliance Holdings and Consumption of Residential Electricity; An Econometric Analysis. Econometrica 52: $345-362$.

16. Rogers, A.S. (2002). Demand of Urban Residential Water in the United States. Land Eco. 55(1): 43 - 58.

17. Edo State Government Open data Portal (2019) Census Population Distribution by L.G.A. 2006.

18. http://www.opendata.edostate.gov.ng/2019/05/16/census-populationdistribution-by-l-g-a-2006/

\section{AUTHORS PROFILE}

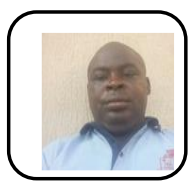

TPL. Kayode Afolabi Bada, is a registered Town Planner(TPL), and Senior Lecturer at the Department of Urban \& Regional Planning, Auchi Polytechnic, Auchi, Nigeria. He holds B.Eng. in Geography, M.S in Urban \& Regional Planning, and Ph.D. (Nearly completed) in the area Urban \& Regional Planning from the Federal University of Technology, Akure, Nigeria. Besides academic/research experience, I am into consultancy. He has served in several committees in the Polytechnic

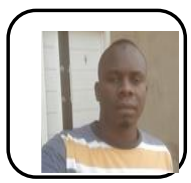

Alhassan, Ahmed Igbeneghu, is a COREN registered engineer and a Lecturer II at the Department of Civil Engineering, Auchi Polytechnic, Auchi, Nigeria. He holds B.Eng and M.Eng in Civil Engineering. He is a former Vice Chairman of the Nigerian Society of in the Polytechnic. Engineers, Edo State. He has served in several committees

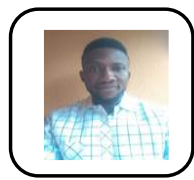

Momoh, Emmanuel Onuche, is an Assistant Lecturer at the Department of Urban \& Regional Planning, Auchi Polytechnic, Auchi, Nigeria. He holds B.Sc and M.Sc in Geography. He has served in several committees in the Polytechnic.

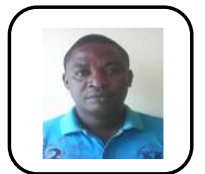

Engr. Olotu Yahaya, is a COREN registered engineer, and Senior Lecturer at the Department of Agricultural \& Bio-Environmental Engineering, Auchi Polytechnic, Auchi, Nigeria. He holds B.Eng. in Agricultural Engineering, M.Eng in Soil \& Water Engineering, and Ph.D. (Nearly completed) in the area of Climate Change from the Federal University of Technology, Akure, Nigeria. Besides academic/research experience, I am into consultancy. He has served in several committees amongst which is the School of Environmental Research \& Development, Auchi Polytechnic Green Revolution, and others.

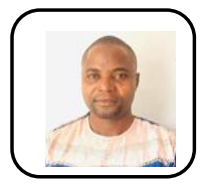

Dirisu, Henry Ogieakhena, is a COREN registered engineer and a Lecturer II at the Department of Civil Engineering, Auchi Polytechnic, Auchi, Nigeria. He holds B.Eng and M.Eng in Civil Engineering. He is a former examination officer and currently NAES staff adviser.

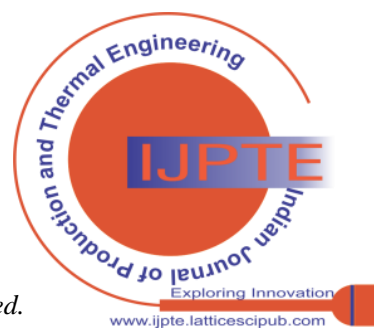

